\title{
Piracy, Property and the Crisis of Democracy
}

\author{
Martin Fredriksson*, James Arvanitakis**
}

*Linköping University, Sweden martin.fredriksson@liu.se, **Institute for Culture and Society, University of Western Sydney, Australia J.Arvanitakis@uws.edu.au

Abstract: A political battle is being waged over the use and control of culture and information. While copyright organisations and most established media companies argue for stricter intellectual property laws, a growing body of citizens, and parts of the new media industry, challenge the contemporary IP-regime. This has resulted in a political mobilisation of piracy. This mobilisation is most evident in the formation of pirate parties, which see themselves as a digital civil rights movement, defending the public domain and the citizen's right to privacy against copyright expansionism and increased surveillance. Since the first pirate party was formed in Sweden in 2006, similar parties have emerged across the world. This article draws on a study of the culture and ideology of copyright resistance, through a series of interviews with representatives of pirate parties in Europe and North America. It focuses on democracy and citizenship in the context of pirate politics. In particular, this article examines challenges to democracy, and the distinction between public and private property and spaces, in the wake of the war on terror and the global financial crisis.

Keywords: pirate parties, digital activism, participation, resistance, democracy, civil rights

Acknowledgements: This research was made possible by funding grants from The Swedish Foundation for Humanities and Social Sciences and the Australian Research Council (Discovery grant DP120104607) along with the generous institutional support of Linköping University, Sweden and the University of Western Sydney, Australia.

\section{Introduction}

Over the last decade the landscape of political activism has changed in many important regards. The central role played by social media and new information technology in the Arab Spring uprisings has often been taken as an example of how the internet may enhance social and political change in countries run by authoritarian regimes. An apparently different digital rights movement has emerged in the Western world. This movement focuses on internet censorship and privacy, and partly consists of organisations like Electronic Frontiers Foundation, Wikileaks, and Anonymous. It is also characterized by temporary and semi-spontaneous digital protests against legislative threats to internet freedoms, such as the rejected SOPA (Stop Online Piracy Act) bill in 
the USA, the failed Anti-Counterfeiting Trade Agreement (ACTA) in Europe; as well as increasing government surveillance such as the [US] National Security Agency's PRISM. In this context, the emergence of the pirate parties, which have spread across Europe and the rest of the world in less than a decade, represents a more formalised political branch of activist digital movements.

This paper relies on findings from a larger study of pirate parties in Europe, Australia and North America. The project was conducted by Martin Fredriksson and funded by The Swedish Foundation for Humanities and Social Sciences. The study has two overarching purposes. Firstly, it presents a wider effort to record the history of a political movement under formation, mapping the development of pirate parties, their turning points, specific and general objectives, and relations to other political and social movements. Secondly, it aims to analyse the movement in relation to the social development of late modernity; and reflects on how pirate politics responds to conflicts and changes in contemporary society.

In this article, we focus on how research participants identified two interrelated crises confronting contemporary politics, crises which have spurred the development of pirate parties. The first is the failure of formal politics to acknowledge the radical democratic potential of the internet. Just as official attempts to fit an entity as amorphous as the internet into established political structures start to mobilise, the second crisis emerges. Traditional economics, which relies on clearly defined property rights, moves in and attempts to enclose the space in which activists

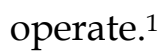

The data consists of semi-structured interviews with representatives of pirate parties in Sweden, UK, Germany, Australia, USA and Canada. All the interviews were done in person, in most cases individually, with the exception of three interviews with groups of 2-3 participants. The interviews in USA were conducted between December 2011 and May 2012, with follow up interviews in May 2013. The European interviews were conducted throughout 2012 and 2013, and the Australian interviews were conducted in 2013. Among the 31 persons interviewed for the entire project, only five were women. Most informants are between 20 and 40 years old, but a few are closer to 45 . The interviews were semi-structured in the regard that they broadly followed an interview guide that was structured around four thematic clusters: the participant's individual motivations, the organization of the party, the ideology of the party, and the national and international context of the party. The interviews also allowed for individual variations within those themes. The material was analysed following a qualitative, inductive methodology. The interviews were recorded and all participants agreed to be quoted by name.

\footnotetext{
1 These attempts have recently been re-opened in Australia as a new government struggles with what previous governments have failed to enclose. See for example James Hutchinson, 'ISPs line up for fresh piracy negotiations', Australian Financial Review, 7 April 2014:

http://www.afr.com/p/technology/isps_line_up_for_fresh_piracy_negotiations_hfKEcCdcgswVVkAT TmFxnK Viewed 13 April 2014.
} 
The participants are specifically regarded as individuals, expressing their own opinions and experiences, and not as formal representatives of a political party, or the movement generally. One reason for this caveat is that the interviews revealed significant differences between the roles and perspectives of respondents and the formalised national parties. While some of the informants from the well-established Swedyish party are political staffers or representatives in the European Parliament, all the American pirate party members are non-professional activists engaged in a subpolity. Some of these are students but most of them hold more or less qualified jobs, sometimes but not always - in the technology sector. Instead of generalising, therefore, this study captures the polyphony of voices within the movement; and analyses individual understandings of the movement and personal motivations for engaging with it.

We begin with a short description of the birth and international spread of the pirate party before presenting the empirical material, with a particular focus on the interviewees" visions of democracy. Finally, we discuss the various views on contemporary economic policies and the global financial crisis that, as will be argued, reveals a broader crisis of democracy.

\section{The Pirate Party}

The history of pirate parties began in Sweden on 1 January 2006 when then-36 year old Rick Falkvinge posted a website declaring his intention to form a Pirate Party dedicated to the legalisation of file sharing. His call had an immediate impact, and greatly exceeded his expectations. The website attracted three million visitors in the first two days, and Falkvinge soon met his initial goal: to collect the 1500 signatures required to register a political party in Sweden (Spender 2009; Fredriksson 2013, 2015a, 2015b).

Even though the party quickly attracted members, it received only 0.63 percent of votes in its first Swedish parliamentary elections nine months later (Rydell \& Sundberg 2010: 115; Spender 2009: 24). Yet three years later, the Pirate Party had its first major breakthrough with the election of two representatives to the 766-seat European Parliament with 7.1 percent of the vote, which represents one tenth of Sweden's twenty mandates in the European parliament (Erlingsson \& Persson 2011).

The Swedish Pirate Party identified three core issues: respect for personal integrity; free access to culture and information; and opposition to patents and private monopolies (Fredriksson 2013). These were largely in response to three key events that contributed strongly to mobilising the Swedish public's concerns around copyright and privacy.

The first was the trial against The Pirate Bay, a file-sharing hub that stood accused of promoting piracy by providing links to a large number of bit-torrent sites. The prosecution was initiated in May 2006 after Swedish police confiscated The Pirate Bay's servers. This raid caused an outcry amongst file sharers and led to an immediate growth of pirate party members, particularly when it was uncovered that the prosecution was partly instigated by pressure from American copyright lobbyists (Spender 2009: 28). The reactions radically intensified in March 2009 when The Pirate Bay 
owners were sentenced to one year in prison and fined 30 million SEK (US\$3.6 million) in a trial clouded by allegations of biased judges (The Economist 2009).

Secondly, there was the heavy-handed implementation of two EU directives on copyright. The Information Society Directive of 2001 (2001/29/EC) harmonised and strengthened the rights of copyright holders in the European Union. Next came the Intellectual Property Rights Enforcement Directive (IPRED) in 2004 (2004/48/EC), granting media companies and copyright organisations extensive powers to monitor individual internet users for the purpose of uncovering copyright violations. When the former was implemented in Sweden in 2005 it was met with strong criticism, which in many ways paved the path for the formation of the Pirate Party. The debates were reignited when the IPRED was implemented in April 2009, just three months before the EU election (Svensson \& Larsson 2009: 17).

A third event was the passing of much-debated legislation governing the powers of the Swedish NSA equivalent, FRA (Försvarets Radioanstalt), in June 2008. This set of laws and amendments extended military authority to monitor and intercept digital communication between citizens. The purpose of the legislation was said to be to fight terrorism and international crime (Proposition 2006.07/63; Rydell \& Sundberg 2010). The law sparked online outrage that soon spread to public protests; thus putting another of the Pirate Party's core issues - privacy - on the mainstream political agenda (Rydell \& Sundberg 2010; Erlingsson \& Persson 2011).

The legislative reforms undoubtedly paved the way for the unexpected success of the Swedish Pirate Party in the 2009 EU election. The party was unable to repeat that success in the national election of 2011, where it attracted a mere 0.65 percent of the vote - a marginal improvement on the 2006 election. In part, this was expected: EU ballots are often considered a "second-order" election, which many voters take less seriously and where new and alternative parties can often garner stronger support (Erlingsson \& Persson 2011: 124). The national result nevertheless came as a disappointment for Pirate Party members. Some took it as sign that the party platform was too focused on information politics to extend its political support.

From a Swedish perspective, the 2011 election seemed to render Pirate Parties a phenomenon that had come and gone. This assumption, however, was soon disproven when the German Pirate Party received almost 9 percent of the Berlin regional election vote in November 2011, securing 15 state parliament seats. This was followed by similar results in other German regional elections in spring 2012: the Pirate Party won 7.4 percent in Saarland; 8.2 percent in Schleswig-Holstein; and 7.5 percent in Nordhein-Westfalen (Bengtson 2012). In the EU-election in May 2014 the German Pirate Party got its first candidate elected to the European Parliament, while the declining Swedish pirates lost their two mandates from 2009 (Geere 2014). Although internal conflicts and subsequent drawbacks have cast a shadow over this initial success, the German Pirate Party nevertheless made a significant impact on German politics and inspired pirate party activists in other parts of the world.

This success did not come from nowhere: the German pirate movement had been brewing for some time. The German Pirate Party, formed in September 2006, was typical in that the 
international mobilisation of pirate parties began almost immediately after the Swedish party was announced: Within a week, similar initiatives had been taken up in five other countries (Rydell and Sundberg 2010: 160). By the end of 2006 an international organisation for coordination and exchange of information - Pirate Parties International (PPI) - was formed. Over the following year national parties were formed in Austria, the UK and the USA. The first pirate parties and the PPI are firmly grounded in a European context. Yet pirate parties have reached every continent, with international expansion to Africa, Australia, the Americas and Asia (PPI 2012).

The pirate party has played a role in Arab Spring developments in Tunisia, where the blogger and pirate party activist Slim Amamou brought the pirate flag to the barricades (Bollier 2011). Amamou's involvement with the resistance movement first saw him jailed by the Ben Ali regime, but after the fall of the regime he served as member of the new parliament for a short period (Christafis 2011). Although this is a relatively isolated incident compared to European developments, its isolation does not change the fact that Amamou was the first Pirate Party member to hold a ministry in a national government.

Typically, when the Swedish Pirate Party first attracted attention and had its first breakthrough at the European elections, it was depicted as a party of discontent. The political mainstream, which had the most to lose from Pirates' success, claimed that pirate politics was founded on a general distrust of established politics, and merely attracted protest votes. However, Erlingsson and Persson (2011) argue that the Pirate Party's impact on the 2009 Swedish EU election depended more on issues-based voting than a protest vote. Their findings indicate that the pirate voters were not primarily guided by a general discontent with mainstream politics but rather by a view that no other parties represented their particular concerns around personal integrity and online file sharing (Erlingsson and Persson 2011: 126).

As the swift emergence of sister parties suggests, the growing concern over privacy and copyright expansionism is not an isolated Swedish phenomenon. The factors that laid the foundation for the growth of the Swedish Pirate Party - the Pirate Bay trial, the aggressive implementation of international copyright directives, and increased government surveillance contributed to mobilisation of the movement, at least in Europe. This was confirmed by interview respondents who stated that the Pirate Bay trial became a symbol of the copyright industry's attack on global file-sharing culture and its (attempted) enclosure of internet freedoms (Interview with Andrew Norton 2012-03-17; Rydell and Sundberg 2010, 160). Several respondents emphasised that the Pirate Bay trial and changes in copyright and information legislation played a significant role in the international mobilisation of pirate parties. This indicates that for the research sites at least (Europe, Australia and North America), digital rights constituted the main driving force behind the pirate agenda.

While the strong focus on digital rights and information politics was crucial to the initial spread of pirate parties, many have since formulated a wider agenda. This is partly inspired by the German party, whose municipal successes in 2011 and 2012 partly relied on its policies of free public transport, basic income guarantees and legalisation of "light" drugs (Piratpartiet 2012a; 2012b; Bauwens 2012). There was a rising awareness among the leadership that the party must 
address a wider range of issues to come across as a credible alternative in national politics (Piratpartiet 2012b).

\section{A Crisis of Democracy?}

As pirate parties spread, and expand their scope beyond core copyright issues, two central questions arise. How can the ideas that were originally formulated in the Swedish environment be translated to other cultural contexts? What other issues, if any, will be added to the agenda in the process?

One key theme that emerged in all the interviews was an attempt to contextualise the core issues regarding rights to privacy and access to knowledge within a wider discourse on democracy. This was not confined to the continent. The opening lines of the UK Pirate Party manifesto, for example, define the protection of democracy (rather than digital rights/information politics) as the basis for the party's existence:

Democracy is in crisis in the United Kingdom. Whether it is online or on the doorstep, people are telling us that they feel alienated, ignored, that they have given up voting as it changes nothing.

(Manifesto, Pirate Party UK: 2)

This reflects the concerns of a wide range of citizenship scholars, across the western democracies in particular, and for some time now (Norris 1999; Putnam 2000; Pusey 2003; Isin and Turner 2007). The idea that democracy is at a crisis point is more or less present in all of the national pirate parties, though most predominant in the parties of the United States, where public confidence in Congress is at an all-time low (Lessig 2011). Interviewee Andrew Norton, who has worked with pirate parties in the UK and the EU and, currently in the US Pirate Party, describes a sense of hopelessness and entrenched political apathy in the USA:

In Europe there is still the "hope of democracy". In the US, it's only a few idealists that cling to the notion that there is a form of democracy and bother to "waste our time" getting involved with US politics outside the rigid confines of the "establishment". (Interview with Andrew Norton 2012-03-17)

The USA respondents articulated two main threats to a free and democratic society: the political influence of corporates, and the authoritarian tendencies of contemporary politics. This critique flows consistently from the party's focus on copyright issues as demanded by the spying agencies and entertainment industry, from the American Copyright Term Extension Act 1998 (the "Mickey Mouse Act") to the Cyber Intelligence Sharing and Protection Act (CISPA). Chris Walsh, former IPlitigator and member of Massachusetts Pirate Party, describes this as a consequence of the old entertainment industry's business model:

...the entertainment industry has this huge library of legal rights and they can get a great return by lobbying to increase the value of those legal rights so it's sort of a big part of their business model to spend money on lobbying to make their rights more valuable. (Interview with Chris Walsh 2011-12-08) 
The second issue - government control - is strongly related to the "war on terror", a recurring subject in almost all interviews and no doubt further accentuated by Edward Snowden's revelations (Khan 2013). Marcus Kesler from the Oklahoma Pirate Party points out that since 9/11 the terrorist threat has replaced the threat of communism as the main excuse for increased surveillance, violations of citizens" privacy, and restrictions on individual freedoms. Reflecting on the authoritarian history of his own country of birth, Germany, Kesler describes how his engagement with the Pirate Party is largely motivated by a fear of authoritarianism:

I can see how a peaceful nation that just wants to do good can very easily one step at the time become something completely different. That's kind of what I'm always worried might happen here... I would like us to be a watch dog ... having the people watch the government instead - instead of the government knowing what we are doing, we have to know what the government is doing. (Interview with Marcus Kesler 2012-03-10)

Kesler's concerns are shared by other USA Pirate Party activists, and are also a central concern in the European context on which he draws. As noted above, the manifesto of the UK Pirate Party defines threats to democracy posed by government surveillance and corporate influence. When discussing the erosion of democracy and civil liberties, the UK Pirate Party emphasises its country as home to "Europe's biggest army of CCTV cameras" as well as stating opposition to gradual privatisation where "all aspects of our society are being divided up and parcelled out". It has become "impossible to find out who is responsible for the most basic aspects of our environment, public spaces and services" (Manifesto, Pirate Party UK: 2).

This sentiment is echoed by the Swedish Pirate Party's two representatives in the European Parliament, who raise concerns regarding corporate influence in EU politics (interview with Amelia Andersdotter 2012-10-02). Christian Engström describes a situation where politicians are subject to the constant influence of corporate lobbyists in a way that resembles conditions in the USA (Interview with Christian Engström 2012-10-03). It is argued that the political and business interests have been intertwined into what Lawrence Lessig (2011) identifies as a system of institutionalised corruption. This consensus around the crisis of democracy comes through in most national pirate parties as an apparently spontaneous consequence of the original focus on information politics.

These concerns are not, however, unique to the Pirate Party movement. Most contemporary political movements share them. What is more characteristic of pirate parties is how closely they envisage democracy and civil liberties as intertwined with information and technology. Travis McCrea, deputy leader of the Canadian Pirate Party, declares: "People always call us a technology party. I always say that we're a civil liberties party, and through civil liberties our technology is protected" (Interview with Travis McCrea 2012-03-02).

This focus on technology can be traced to a shared heritage with the hacker and open source movement, where technology provides not only a tool but also "a logic" for social interaction (Fredriksson 2013). Some pirate party-ists claim that the open source mentality has made the pirate movement less centralized than traditional political parties - reflecting the amorphous growth of movements to which the pirate parties have in part responded, such as the Arab Spring and 
Occupy. By keeping the organisation open and refusing to allocate power to individual representatives or fixed institutions, the movement aims to be more vital and democratic, as well as more resistant to co-option from other interests - since there are no centres of power to enclose (Fredriksson 2013).

The chair of the Swedish Pirate Party's youth organisation, Gustav Nipe, emphasises this while also arguing that if many members initially saw the pirate party as a temporary intervention on a particular political issue, it is now an increasingly institutionalised, long-term movement:

The open source people see the party as a hack:

We have a political problem, let's fix it... I saw it that way for some time - that the Pirate Party was just a temporary thing to fix a small problem. While others see the party as being... to create those big processes and the big party bureaucracy where the essence of politics is created (Interview with Gustav Nipe, 2012-11-01)

Reflecting this perspective, what can be considered as starting out as "single hack" soon expanded into something that aims to be a "system re-set". This is a necessary consequence of the fact that information politics are deeply entwined with existing power structures and political and commercial interests. What was at first seen as a "small" and "political" problem, therefore, cannot be approached as a single problem. Chris Walsh from the Massachusetts Pirate Party agrees that fixing what initially appears to be a single issue requires more fundamental political change:

I think it's a realization that you come to in the US if you are an expert in any policy area and you look at what's going on in Washington and you try to figure out why the good policies aren't being enacted or even talked about ...I think [Lessig] came to the conclusion that there will be no fixing copyright until you fix the underlying problem with the influence of money on politics (Interview with Chris Walsh 2011-12-08).

Walsh's and Lessig's more systematic approaches to politics are in line with Nipe's description of the open source philosophy as a kind of intuitive, organic mind-set: "open source is an organism" (Interview with Gustav Nipe 2012-11-01). The free and collaborative values associated with open source programming are consistently referred to as providing the rationale and potential for a new and more democratic way to organise politics and, in the long run, society at large. Anthropologist Gabriella Coleman claims that the open source movement has become a "legal and collaborative methodology" for different kinds of social movements; a "pragmatic template by which many other social groups have modelled and directed their endeavours" (Coleman 2005: xxviii).

The pirate movement also employs this strategy as it interfaces with multiple local and global social movements, including Occupy (Interview with Jay Emerson 2012-04-21; Interview with Zacary Adams Green, Aleyisha and Yoni 2013-05-11). The relation between pirate parties and North African protesters may seem more far-fetched, but many of the pirate party-ists interviewed saw the Arab Spring as another example of a political implementation of open source values that are reflective of the pirate movement. There are also more concrete interactions: the international pirate movement supported protesters in North Africa by providing access to digital media 
channels - most notably through the activist group Telecomix - which saw rebel elements in Egypt rout around authorities" attempts to shut down free internet forums (Fredriksson 2013; Madlena 2011).

\section{A Crisis of Capitalism?}

The second crisis that emerges as a theme in the interviews is the crisis of capitalism and the failure of the market to provide public access to culture and knowledge in the information society. The Swedish political scientist Marie Demker (2011) understands the Pirate Party as a reaction to the information society's new political "cleavages". Demker argues that fundamental political oppositions grow out of a social order, and serve as the basis for political mobilisation. She contends that if the industrial revolution gave rise to those cleavages between Owner-Worker and Urban-Rural which formed the political landscape of the 1900s, then the communicative revolution has created a set of new cleavages between Knowledge-Market and Network-State. It is from the flaws in these arrangements that the Pirate Party agenda has emerged.

In this regard, Demker's position largely corresponds to Pirate Party self-conception. Many pirates envision themselves as acting at a historical turning point, where law and politics are yet to catch up with the social and technological changes of the information age. Henrik Brändén of the Swedish Pirate Party's executive committee (until December 2014), points out that we are at a defining moment in the history of production. Even if we do not yet know if it is as decisive as the shift from an agricultural to an industrial economy, he contends that there is no doubt this is a similar kind of transformation (Interview with Henrik Brändén 2012-10-29). The situation requires more than a "quick fix" of failed information politics. There is a glaring need for new political platforms, based on an updated analysis of society, similar to the way Greens parties introduced ecology into mainstream politics in the 1970s and 80s. Brändén also sees the Pirate Party as "the next new force in politics after the environmental movement" (Interview with Henrik Brändén 2012-10-29).

Even though pirate parties rarely take a specifically anti-capitalist stance, the articulation of piracy as a basis for a political movement reflects the crisis of capitalism in a number of different ways. Three such examples are of particular importance here. The first is the way that the information society affects not only modes of communication, but also modes of production. Consequently, bad politics under the influence of powerful lobbyists obstruct social, cultural, and economic development. Crisis-ridden democracy lets lobbyists for an outdated segment of the media industry set the agenda in Washington and Brussels, and 21st century entrepreneurs must join the enclosure agenda, or be shut out:

the interests of the lobbyists rule, which are to support old business, which always happens at

the expense of the new ... so EU represents an economic conservatism and a hostility towards the market which is harmful for the economy. (Interview with Christian Engström 2012-10-03)

Engström's words, as well as Walsh's previous statement about how the old media industry sets the agenda in Washington, also tells of a conflict within capitalism where old and new media 
businesses have different copyright agendas. The traditional entertainment and the technology industry can be seen as two opposing business models where the big film and music companies strive to maintain and extend their control over information through intellectual property while companies like Google, Youtube and Facebook make money from distributing user generated material or content that is for other reasons in the public domain and thus benefits form a more liberal copyright regime (Jacobsson 2012; Fredriksson 2015a, 2015b).

The second way that pirate politics connects to the crisis of capitalism is highlighted by Engström's and Lessig's concern that "institutional corruption" and the influence of large scale corporate lobbyism may undermine the free market from within. This critique is firmly grounded in a liberal perspective that is quite common across pirate parties. The pirates critique the malfunctions of contemporary capitalism, but not necessarily from a left wing or especially radical perspective. American media scholar Patrick Burkart posits that pirate parties do not compose a socially radical movement, but rather predominantly middle-class organisations which avoid addressing economic (re)distribution and anti-capitalist rhetoric:

In contrast, pirate politics merely tweaks the logic of existing regimes. The Pirate Party and its supporting movements represent a new middle-class interest in preserving dominant social institutions, including capitalism, as well as privileged positions within them. (Burkart 2014: 57)

This seemed to be confirmed by interview respondents who, with few exceptions, refuse to position the party on the left-right spectrum - a frame that has, arguably, been declining in relevance since mass movements and interest groups mobilised as genuine political alternatives from the 1970s (Warhurst 1991). According to Mattias Bjäremalm, political secretary for the European parliament representative Amelia Andersdotter, the new and more comprehensive agenda that the Swedish Pirate Party is currently developing is likely to become a line in the sand for some of the members farther to the (traditional) left or right:

In the beginning you could be an outright neoliberal or an outright syndicalist and still be a pirate party-ist without any conflict. But if you look at the process of widening the agenda we will probably land in some kind of social liberal middle-of-the-road position. (Interview with Mattias Bjäremalm 2012-10-02)

With the new agenda of 2012, the party made a clear statement against conservatisms on issues of migration, gender and sexual politics, while at the same time refusing to "pick sides" between classical, neo- and social liberalism and purer strands of socialism, by not taking a position on wealth re-distribution via taxes or social security (Piratpartiet 2012b).

Though similar tendencies are found in the UK Pirate Party manifesto (2012), it appears more open to traditional left-right analysis. For example wealth redistribution and Keynesianism (particularly in the wake of the 2008 Global Financial Crisis) appear alongside a mix of liberal policies for small business. The UK manifesto contains some emblematic left wing reforms, such as the possibility of a citizen income (a basic, unconditional salary for all citizens) and the passing of a so-called Robin Hood tax (a tiny tax on financial transactions aimed at impeding destructive financial speculations). The latter is particularly interesting in that it resembles the Tobin tax that 
came to be a core issue for the counter-globalisation movement Attac (Association for the Taxation of financial Transactions and Aid to Citizens) in the 1990s (Martin and Shumann 1996). The basic difference is that the proposed Robin Hood tax is more comprehensive. It would cover a wide range of financial assets, such as stocks and bonds, whereas the Tobin tax only applied to international currency transactions.

Despite the pirate party agenda revealing no radical ambitions to overthrow capitalism, the approach includes a clear purpose to re-set and update political and economic systems. More radical reforms like the Robbin Hood tax reflect a third dimension of the crisis of capitalism: the rise of corporations that are "too big to fail". That the pirate movement in some aspects echoes earlier counter-globalisation movements appears to be a timely response to the ongoing financial crisis, which after all reflects many of the problems addressed by Attac (Martin and Shuman 1997) and Occupy. Among the biggest concerns to democracy and the failure of capitalism are bank bailouts, lack of transparency and accountability of multi-national corporations, rapid and often corrupt privatisation of public resources, and the undermining of national sovereignty by transand multi-national corporations, markets and financial institutions, including via heavy handed and heavily skewed global trade deals (Varoufakis 2011).

The pirate parties, then, frequently intersect with the counter-globalisation tendencies that characterise contemporary social movements (Arvanitakis 2007) while coming from a different angle. Rather than focussing on an anti-capitalism agenda, pirates approach the processes of globalisation from the perspective of information politics. Information politics have increasingly been a site of struggle in global trade relations over the last 20 years, most notably over the World Trade Organization (WTO) TRIPS agreement of 1994 (Gervais 2002). The TRIPS, or “Trade-related Intellectual Property" requires all member countries of the WTO to adopt a set of international rules on intellectual property, via domestic legislation (Drahos and Braithwaite 2003; Fredriksson 2012; Gervais 2002). The EU Information Society Directive (2001/29/EC), framed largely as part of a strategy to promote EU members' creative industries (Fredriksson 2012, 2013, 2015a, 2015b; Guibault et al. 2007) is another example of the economisation of copyright.

Just as the so-called anti-globalisation movement never objected to globalisation per se, but rather protested capitalism's uneven distribution of power and resources, any reference to the pirate party movement as "anti-globalisation" is somewhat misleading. The pirate movement is itself a highly globalised movement. Pirates, however, take activism to a higher level of globalisation through their high-end use of technology. In this regard the pirate movement is an example of the kind of digital activist network that Saskia Sassen sees as parallel, yet opposite, to the global financial market: "The fact that local political initiatives can become part of a global network parallels the articulation of the capital market with a network of financial centres" (Sassen 2004: 83).

While these two forms of global networks rely on the same technological infrastructure, they tend to lead to different outcomes, as "the same technical properties produced greater concentration of power in the case of the capital market and greater distribution of power in the second case“ (Sassen 2004: 84). Like the capital market, digital activist networks have a capability 
of "being global without losing the focus on specific local condition/resources" (ibid). In this sense, national pirate parties could be regarded as local mobilisations of a global activist network which resists the internationalisation of intellectual property laws, which are in turn a manifestation of the forces of economic globalisation,

\section{A Crisis of Property}

At the most fundamental level the politics of piracy can be seen to articulate a destabilisation of "private" property that is also fundamental to the crisis in capitalism. Pirate politics are implicitly engaged with an ongoing crisis of property, across both the intellectual property and financial markets spaces. One reason for a looming deadlock in the piracy debate lies in the collision between two radically different ways of perceiving file sharing. While pirates see the sharing of art and culture as a communicative act, and regard the attempts to stop it as censorship, old media industries see such sharing as distribution of stolen goods. This in turn leads to the crucial distinction between defining culture and information as creative output for sharing (or not), as founding rights derived from output, or as a commodity first and foremost. These distinctions are increasingly destabilised when it comes to "immaterial" works in the digital context.

The crisis of property rights is not limited to immaterial goods. The distinction between what is a right and what is a property is crucial to restructuring social states, where neoliberal ideology demands commodification of resources that were once publicly provided, such as healthcare or education (Arvanitakis 2006). This crisis of property is interlinked with the collapse of the financial sector where the clear delineation of who owns what - the very basis of capitalism - is disintegrating.

Here again is the "too big to fail" corporation, as financial interests have somehow convinced even social democratic-leaning governments as well as the public, that nationalising losses but not profit is somehow valid public policy. Here, the public are forced to carry the risks and losses of private speculations by banks and other finance companies, from which the profit has already been taken by the "business" and its staff. Business simultaneously lobbies for asset sales, their sights set on further co-opting of profit from publicly owned and funded resources to private interests. Thus the GFC and crises of democracy are deeply entwined, anchored in fiercely contested definitions of property and commodity - and, as always, by greed. The pirate parties may appear to go beyond the distinction between left and right, but their initial core focus on filesharing and freedom of information in the face of copyright expansionism is entrenched in a wider discourse concerning the failures and other consequences of capitalism in an information age (Fredriksson and Arvanitakis 2014).

These consequences can be discussed in detail by drawing on the work of Sonja Schillings (2014: 88) who sees the emergence of digital piracy as the first "comparatively big community to consciously consider ways in which piratical community can be organized" since the Golden Age of pirates in the seventeenth century. For Schillings, it is both the form and structure of the 
contemporary pirate movements which must be understood and which we have attempted to analyse in this paper.

The Pirate Bay founder's self-assured resistance to the copyright industry, and Swedish Pirate Party founder Rickard Falkvinge's conscious refusal to "feel shame" are deliberate instances of "reclaiming a word" for the purpose of defining piracy as "an alternative point of view to the established property regime" (Spender 2009:26). It is from this position that Schillings articulates the fundamental questions of late modernity piracy: "who legitimately defines property?" And, as continuously evoked by the likes of Anonymous and Wikileaks: "who may legitimately own and control information?" (Schillings 2014: 89). While property rights and ownership have always created hierarchies of power, which must be understood intersectionally (that is, in terms of a cultural hegemony of white patriarchy) Schillings' conclusion applies across orthodox and pirate politics, encapsulating both capital market agitation over file-sharing and piratical responses: the crisis of property is that it can no longer be centrally defined. The shifting attitude towards copyright among old and new media businesses indicates that there is not even a capitalist consensus on the definition of immaterial property. File sharers can use the abyss of the internet to re-frame ownership, even if using the same terminology and discourse as existing intellectual property law and the former age of piracy, when the vast and lawless unknown was merely the high seas.

\section{Conclusion}

Based on a series of in-depth interviews with pirate party activists from Sweden, UK, Germany, Australia, USA and Canada, this paper has outlined the philosophical thread that unites various pirate parties. Though originally depicted as a manifestation of cyclical "protest votes" in the 2006 Swedish elections and subsequent 2009 EU elections, pirate parties have continued to exist. Based on philosophical positions pioneered by the open source movement, the pirate parties capture interrelated crises: the legitimacy of democracy and illegitimacy of post-GFC capitalism. The position expressed is, in most cases, not one of anti-capitalism, but is nevertheless, one that demands a systemic reset rather than shallow reforms.

The rise of the pirate parties may be followed by a dramatic fall. But as information technologies continue to be further embedded in our everyday experiences, the politics represented by this movement are less likely to dissipate than to take an alternative shape. Rather than ignoring such developments, established democratic structures must see how new movements, like the Pirate Party, highlight changing conflicts and dilemmas in contemporary society that are soon to surface as major political problems. If we cannot see this, then the crisis in both democracy and capitalism will continue.

\section{References}

Arvanitakis J. (2006). The Commons: Opening and Enclosing Non-commodified Space, Portal: Journal of Multidisciplinary International Studies, 3(1). 
Arvanitakis J. (2007). The Cultural Commons of Hope: The Attempt to Commodify the Final Frontier of the Human Experience. Verlag, Berlin.

Bauwens, M. (2012). A German Pirate Party could bring a European Coalition. Al Jazeera. Retrieved May 26, 2012, from http://www.aljazeera.com/indepth/opinion/2012/04/2012416102253184145.html.

Bengtsson, H. A. (2012). Piraternas återkoms. Dagens Arena. May 14, 2012. Retrieved May 15, 2012, from http://www.dagensarena.se/ledare/piraternas-aterkomst/.

Burkart, P. (2014). Pirate Politics: The New Information Policy Contests. Cambridge. Mass.: MIT Press.

Christafis, A. (2011). Tunisian Dissident Blogger Takes Job as a Minister, The Guardian, 18 January 2011. Retrieved June 25, 2014, from: http://www.theguardian.com/world/2011/jan/18/tunisia-dissidentblogger-minister

Cieply, M. \& Wyatt, E. (2012). Dodd calls for Hollywood and Silicon Valley to meet. New York Times, 19 January, 2012.

Coleman, G. (2005). The Social Construction of Freedom in Free and Open Source Software: Hackers, Ethics and the Liberal Tradition. Chicago: University of Chicago.

Coleman, G. \& Golub, A. (2008). Hacker Practice: Moral genres and the Cultural Articulation of Liberalism. Anthropological Theory, 8, 255-277.

Demker, M. (2011). Sailing Along New Cleavages: Understanding the Success of the Swedish Pirate Party in the European Parliament Election 2009. Conference paper, ISA Annual Conference 2011. Retrieved June 20, 2013 from http://citation.allacademic.com/meta/p_mla_apa_research_citation/5/0/1/1/5/pages501155/p50115 5-1.php

Drahos, P. and Braithwaite, J. (2003). Information Feudalism: Who Owns the Knowledge Economy. New York: The New Press.

The Economist (2009, September 5). Keeping Pirates at Bay. Retrieved November 21, 2010, from http://www.economist.com/node/14299558.

Erlingsson, G. O. \& Persson, M. (2011). The Swedish Pirate Party and the 2009 European Parliament Election: Protest or Issue Voting? Politics, 31(3), 121-128.

Fredriksson M. (2012). Piracy, globalisation and the colonisation of the Commons. Global Media Journal: Australian Edition. 6(1). Retrieved March 11, 2015, from http://www.hca.uws.edu.au/gmjau/archive/v6_2012_1/martin_fredriksson_RA.html

Fredriksson, M. (2013). An Open Source Project for Politics: Visions of Democracy and Citizenship in American Pirate Parties. In, J. Arvanitakis \& I. Matthews, I. (Eds.), The Citizen in the 21st Century. Oxford, UK: Interdisciplinary Press.

Fredriksson, M. (2015a). The Pirate Party and the politics of communication. International Journal of Communication, 9, 909-924. 
Fredriksson, M (2015b). Pirates, Librarians and Open Source Capitalists: New alliance in the Copyright Wars. In H Porsdam (Ed), Copyrighting Creativity: Creative Values, Cultural Heritage Institutions and Systems of Intellectual Property, Farnham: Ashgate. 153-167.

Fredriksson, M. \& Arvanitakis, J. (2014). On Piracy. In M. Fredriksson \& J. Arvanitakis (Eds.), Piracy: Leakages from modernity (pp. 217-239). Sacramento, CA: Litwin Books.

Geere, D. (2014). Europe"s Pirate Parties are Sinking, but they“ve Already Won, Wired, 26 May 2014. Retrieved August 26, 2015 from: http://www.wired.co.uk/news/archive/2014-05/26/pirate-party

Gervais, D. J. (2002). The Internationalization of Intellectual Property: New Challenges from the Very Old and the Very New. Fordham Intellectual Property, Media and Entertainment Law Journal, 12(4), 929990.

Isin, E., \& Turner, B (2007). Investigating Citizenship: An Agenda for Citizenship Studies, Citizenship Studies, 11(1) 5-17.

Kelty, C. (2005). Geeks, Social Imaginaries, and Recursive Publics, Cultural Anthropology, 20(2) 185-214.

Kelty, C. (2008). Two Bits: The Cultural Significance of Free Software. Durham: Duke University Press.

Khan, Saeed A. (2013). Citizen Fugitive or Citizen Activist? Between State Citizenship and Global Citizenship in the Era of Surveillance and National Security. The Citizen in the 21st Century Conference, 6-8 November 2013: Athens.

Lessig, L. (2011). Republic Lost: How Money Corrupts Congress - and a Plan to Stop it. New York, NY: Twelve.

Madlena, C. (2011). Tech Support for the Arab Spring, The Guardian, 7 July 2011. Retrieved May 9, 2013, from http://www.guardian.co.uk/technology/2011/jul/07/telecomix-arab-spring.

Martin, H.P. \& Shumann, H. (1996). Die Globalisierungsfalle: der Angriff auf Demokratie und Wohlstand, Renbek bei Hamburg: Rowohlt.

Norris, P. (Ed.) (1999). Critical Citizens: Global Support for Democratic Government. Oxford, UK: Oxford University Press.

Philip, K. (2005). What is a Technological Author? The Pirate Function and Intellectual Property. Postcolonial Studies, 8(2), 199-218.

Pirate Party International. (2012). Retrieved on December 12, 2010 from, http:/ / pp-international.net/

Pirate Party International, List of Pirate Parties. Retrieved June 18, 2013 from, http://wiki.ppinternational.net/List_of_Pirate_Parties.

Pirate Party UK. (2012). Manifesto. Retrieved June 18, 2013, from http://www.pirateparty.org.uk/media/uploads/Manifesto2012.pdf

Piratpartiet (2012a). Principer. Retrieved June 18, 2013, from http://www.piratpartiet.se/ principer

Piratpartiet (2012b). $\mathrm{Nu}$ breddas Piratpartiet! Retrieved May 26, 2013, from http:// breddning.piratpartiet.se/om-den-har-sidan/. 
Proposition 2006.07/63, En anpassad försvarsunderrättelseverksamhet, [proposition to the Swedish Parliament, Adaptions of the National Intelligence Activity]

Pusey, M. (2003). The Experience of Middle Australia: The Dark Side of Economic Reform. Cambridge. UK: Cambridge University Press.

Putnam, R. (2000). Bowling Alone: The Collapse and Revival of American Community. New York: Simon \& Schuster.

Rydell, A. \& Sundberg, S. (2010). Piraterna: Historien om The Pirate Bay, Piratpartiet och Piratbyrån, Stockholm: Ordfront.

Sassen, S. (2004). Electronic Markets and Activist Networks: The Weight of Social Logics in Digital Formations. In R. Latham and S. Sassen (Eds.). Digital formations: IT and New Architectures in the Global Realm. Princeton University Press, Princeton.

Shillings, S. (2014). Piratical Community and the Digital Age: The Structural Racialization of Piracy in European Law and Culture. In M. Fredriksson \& J. Arvanitakis (Eds.). Piracy: Leakages from Modernity (77-94). Sacramento, CA: Litwin Books.

Spender, L (2009). Digital Culture, Copyright Maximalism and the Challenge to Copyright Law. University of Western Sydney: Sydney.

Svensson, M. \& Larsson, S. (2009). Social Norms and Intellectual Property: Online Norms and the European Legal Development. Lund: Lund University.

Who are Tunisia"s Political Parties? Al Jazeera, 27 October 2011. Retrieved May 24, 2012, from http://www.aljazeera.com/indepth/features/2011/10/201110614579390256.html.

Warhurst, J. (2007). Behind Closed Doors. Sydney, UNSW Press.

Wikipedia - Pirate Party (2012) retrieved May 31, 2012.

Wikipedia - List of Pirate Parties (2013). Retrieved June 18, 2013.

Varoufakis, Yannis (2011). The Global Minotaur. London: Zed Books.

\section{Interviews}

Interview with Chris Walsh, Cambridge, December 8, 2011

Interview with Travis McCrea, Vancouver, March 2, 2012

Interview with Marcus Kesler, Oklahoma City, March 10, 2012

Interview with Brad Hall, Jacksonville, March 14, 2012

Interview with Andrew Norton, Marietta, March 17, 2012

Interview with Jay Emerson, New York, April 21, 2012

Interview with Amelia Andersdotter, Brussels, October 02, 2012 
Interview with Mattias Bjäremalm, Brussels, October 02, 2012

Interview with Christian Engström, Brussels, October 03, 2012

Interview with Henrik Brändén, Uppsala, October 29, 2012

Interview with Gustav Nipe, Uppsala, November 01, 2012

Interview with Zacary Adams Green, Aleyisha \& Yoni, New York, May 11, 2013

\section{About the Authors}

\section{Martin Fredriksson}

Martin Fredriksson is an assistant professor and Marie Curie Fellow at the Department of Culture Studies (Tema Q), Linköping University and visiting scholar at the Institute for Culture and Society, University of Western Sydney. He is currently conducting a project about 'Commons and Commodities: Knowledge, Natural Resources and the Construction of Property' funded by the Swedish National Research Council. He has previously worked with the history of copyright in Sweden and with piracy as a social movement, conducting extensive studies of Pirate Parties in Europe, North America and Australia.

\section{James Arvanitakis}

Professor James Arvanitakis is the Dean of the Graduate Research School and the Head of The Academy at the Western Sydney University where he is also a lecturer in the Humanities and a member of the University's Institute for Cultural and Society. He is also an Academic Research Fellow at the University of Witswatersand, Johannesburg. His research areas include citizenship, resilience, piracy and the future of universities. In 2015, James will be releasing two new books: Sociologic - a new sociology textbook (Oxford University Press) and Citizen Scholar and the Future of Universities (Palgrave). 